\title{
What matters? The role of values in transformations toward sustainability: a case study of coffee production in Burundi
}

\author{
Milda Nordbø Rosenberg ${ }^{1}$
}

Received: 8 September 2020 / Accepted: 11 May 2021 / Published online: 18 June 2021

(c) The Author(s) 2021

\begin{abstract}
This paper examines the role of values in transformations toward sustainability. Values, generally defined as what people deem to matter, are increasingly gaining interest in and outside of academia. For example, sustainability aligns with specific values such as dignity, equality, safety, and harmony for people and nature. However, current approaches to values are mindmatter dualistic, and therefore failing to honor the inherently dynamic relations of socio-ecological systems. Drawing on new materialism, I explore values as part of the relations that make this world and propose to consider values as materialdiscursive practices. Ethnographic fieldwork was done in 2017 with coffee producers in Burundi who aimed to transform production by caring for the coffee and people that grow it. Based on interviews and participatory observation, I present how values were integral to transforming the relational aspects of coffee production. In this study, values of togetherness, care, dignity, and faith were dominant and were found to reconfigure the socio-ecological system of coffee production. I argue that values are inseparable from, and hence co-productive of, the material world that we experience and play a vital role in sustainability transformations.
\end{abstract}

Keywords Values $\cdot$ Transformation $\cdot$ Sustainability $\cdot$ New-materialism $\cdot$ Coffee $\cdot$ Burundi

\section{Introduction}

"We want dignity and value for each individual; it is about grace and love in the community. (...) Team, we are all a team. Farmers are part of the team. I hope you understand that we are working for something bigger than yourself. You get to be part of something exciting". This speech was given by the founder of a company aiming to transform Burundi's coffee production. References to values permeate the speech to motivate and connect the staff ahead of a challenging coffee harvest. What do values mean for transformation?

Transformation is a process of fundamental change (Feola 2015). Yet, despite efforts to transform society toward sustainability, we are confronted by rising global temperatures, diminishing biodiversity, increased financial inequality, and

Handled by Julia Bentz, Nova University of Lisbon, Portugal.

Milda Nordbø Rosenberg

mildajn@uio.no

1 Faculty of Social Sciences, Department of Sociology and Human Geography, University of Oslo, Oslo, Norway reduced human well-being, not to mention a global pandemic (Shrivastava et al. 2020; Hochachka 2020). After years of separate scholarly attention to both transformations and sustainability, sustainability transformations have emerged as an integrated focus of research (Salomaa and Juhola 2020; Shrivastava et al. 2020). Although the natural sciences have historically dominated the social sciences and humanities in sustainability research, in recent years, the role of values, worldviews, and beliefs in global change processes has been highlighted (Shrivastava et al. 2020; Fazey et al. 2018; Patterson et al. 2017). These human dimensions are captured in definitions of sustainability transformations. For example, Patterson et al. $(2017$, p. 2) define sustainability transformations as "fundamental changes in structural, functional, relational, and cognitive aspects of socio-technical-ecological systems that lead to new patterns of interactions and outcomes" (Patterson et al. 2017, p. 2). Their definition draws attention to the fundamental role of relational dimensions in transformative change processes.

In this paper, I focus on the role of values to dive deeper into the relational aspects of transformation. Within the literature, values are presented either as barriers or leverage 
points for fundamental change processes. For instance, values motivated by conservation are found to contribute to resistance to climate change adaptation (Nielsen and Reenberg 2010; Kuruppu 2009; Curry et al. 2015), and values motivated by self-enhancement are negatively related to environmental concern and behavior (Schulz, MartinOrtega, and Glenk 2018; Hicks et al. 2015; Poortinga et al. 2019). These studies refer to values as stable entities within the human mind and related to environmental attitudes and behavior. From this point of view, values are hard to change, making them a barrier to transformations (Nielsen and Reenberg 2010; Wolf, Allice, and Bell 2013). At the same time, recent publications on sustainability transformations recognize that values influence how humans relate to the environment and note that they can and need to change, both within and across generations (Shrivastava et al. 2020). Values are also suggested as powerful mechanisms of transformative change in the reconfigurations of social relations (Few et al. 2017). Such perspectives on values recognize that they can serve as leverage points for systems change, in particular when they contribute to new perspectives and paradigms (Meadows 1999; Fazey et al. 2018). Such notions contrast with the idea that values are stable and resistant to change.

So, what are values? Are values "held" by individuals and communities, and if so where? Are they stable, or can they change? It is problematic that the role of values is frequently mentioned as important for transformations without being fully understood (Patterson et al. 2017; Few et al. 2017; Blackburn 2018; Shrivastava et al. 2020). Answering these questions is necessary to determine whether values such as dignity, equality, safety, and harmony with people and nature can change within a generation ("The 2030 Agenda" 2015; Shrivastava et al. 2020; Patterson et al. 2017). Understanding the role of values in transformations toward sustainability requires a deeper engagement with the concept, exploring how values are a dynamic part of the unfolding evolution of social-ecological systems.

This paper examines the role of values in transformations toward sustainability. In joining the recent work on bridging the dichotomy between nature and society in sustainability transformations (Walsh, Böhme, and Wamsler 2020; West et al. 2020), I step away from an either/or perspective on values (i.e., as fixed or fluid), and instead engage with them as material-discursive practices of what people deem to matter. Rather than being stable subjective ideas or social constructions, values contribute to the emerging and ongoing ebb and flow of the material world. This focus draws on new materialism, a relational school of thought describing discourses and materiality as being mutually related (Barad 2007). New materialism provides us with ways of understanding how values can contribute to sustainability transformations and transcend rifts between dichotomies such as social-ecological and mind-matter (Walsh, Böhme, and Wamsler 2020; Ingold 2004).

While new conceptual understandings are important, sustainability transformations also need empirical studies to support them. Some claim that without these, sustainability transformations cannot be called an empirical phenomenon (Salomaa and Juhola 2020). Based on an empirical study of a specialty coffee company aiming to transform coffee farming in Burundi, I explore the role of values in sustainability transformations. In this study, I witnessed values forming collectively, not within a generation, but within a coffee harvest season. Based on this, I argue that values are not as fixed as assumed. This promising insight suggests that sustainability-related values can be put into practice by the current and future generations, and within a short time period. This finding supports the idea that values are material-discursive practices that configure the relations within socio-ecological coffee production systems.

I start by reviewing the dominant approaches to values and then present the concept of material-discursive practices, drawing on new materialism. Then I describe the case study setting and outline the ethnographic design and methodology. Next, I present how values are entangled with the materiality of coffee production, and I discuss what values as material-discursive practices entail and how they are part of unfolding transformation. Finally, I consider the implications of approaching values as material-discursive practices for sustainability transformations.

\section{Theoretical approaches to values}

The word "value" is so prevalent that it risks losing its value due to vague and all-encompassing use (Rohan 2000; Few et al. 2017). In the most general way, values refer to what individuals or groups deem to matter (Kenter et al. 2019; Schwartz 1994). However, the range of value definitions, theories, and frameworks is not surprising, considering the many disciplines that research values (for a recent systematic review, see Rawluk et al. 2019; Kenter et al. 2019). What is clear is that each discipline approaches values with different ontologies and epistemologies, leaving the term in a "messy" and an incommensurable place (Kenter et al. 2019). Out of the numerous approaches, I focus on two camps in which theoretical knowledge of values research has mostly diverged before suggesting an alternative. One approach considers values as individual and stable over time, while the other considers values as socially constructed and always shifting (Kenter et al. 2019). 


\section{Held values}

Social psychology scholars tend to conceptualize values as being deeply held by individuals (Rawluk et al. 2019; Schwartz 1994). Values refer to subjective and prescriptive beliefs of whether behaviors or outcomes are desirable and serve as guiding principles (Rokeach 1973; Schwartz and Bilsky 1990). Values are thought of as pre-formed and somewhat stable. They can, therefore, be meaningfully isolated and elicited through self-reporting (Schwartz and Bilsky 1990). Individual values can also be aggregated to reveal shared values among groups of people or societies (Bardi and Schwartz 2003; Schwartz and Sagie 2000). Such notions from social psychology have increasingly been adopted interdisciplinarily by environmental social sciences; for example, to explain how disagreements on climate change adaptation strategies, ecosystem services, and water policies are rooted in conflicts between deeply held values (Schulz, Martin-Ortega, and Glenk 2018; Hicks et al. 2015; Poortinga et al. 2019). As such, they claim to reveal in-depth aspects of environmental conflicts (Ford et al. 2009; Ives and Kendal 2014). Conceptions of held values located within the individual mind have dominated values research since its infancy (Lovejoy 1950; Rokeach 1973). However, providing insights into subjectivities by reducing people to their values, as something that can be objectively known, has increasingly been questioned over the last 30 years. Such critiques target the foundational dualism of approaching the world as separate from humans (Walsh, Böhme, and Wamsler 2020; Mansfield 2000).

\section{Constructed values}

Constructivist scholars view values as embedded into larger social structures, cultures, and worldviews that are under constant construction (Irvine et al. 2016; Ives and Kidwell 2019). Values are assessments of how something ought to be, and they are defined through socially constructed discursive practices used to legitimize society (Harvey 1996). Within this perspective, individual values cannot be captured or meaningfully known because they are formed continuously in different situations and positioned outside the mind. This makes it meaningless to then talk of shared values based on aggregated individually "held" values (Irvine et al. 2016). For example, a study by Irvine et al. (2016) shows how shared values formed in response to a suggested change in public forest ownership. People identified the importance of forests for future generations and asserted that "these forests are ours" for the whole population's common good (Irvine et al. 2016, p. 188). These authors suggest that 'forest' values may not have existed prior to all the participants but were generated during the collective response provoked by the forest ownership change. Therefore, some values seem to form collectively and are different from what people may deem to matter in isolation (Irvine et al. 2016). The stark difference from the previous perspective is that values are never really individual or constant within the mind, but are instead in an ongoing process of being formed and re-formed in structures outside the mind. Both perspectives ascribe to a dualistic perspective of the world by positioning values within or outside the mind, without addressing the intrinsic relations between the entities.

\section{Values as a material-discursive practice}

One way to honor socio-ecological dynamics is by approaching values as an integral part of the whole. I do so by suggesting that values are material-discursive practices. Values as material-discursive practices have not been explored thoroughly in values research, but build on a long tradition of materialist approaches within social science (Haraway 1991; Pulido 2000; Parker 2016). For example, representational gender discourses are argued to have material real-world effects (England 2004). Gender is not only a discursive representation of the predominantly masculine-feminine binary, but has material consequences, for example, in how young girls construct and reproduce themselves and their households (Hyams 2003). Gender, race and class emerge throughout the entangled dynamics of discursive imaginations and material articulations (Massey 1994; Haraway 1991; Harvey 1996). Echoing the materialist perspective on gender, race, and class, I argue that it is worth considering values-ideas about what matters to people — as similar material-discursive practices.

Materialist approaches have developed over time, and new materialism has joined the field by offering a perspective where materiality and discursivity are fundamentally entangled rather than distinct entities that affect one another causally (Barad 2007). New materialism is concerned with matter in response to the growing realization that reality is much more entangled, and open-ended than previously assumed, and therefore full of possibilities (Barad 2007; West et al. 2020). New materialism is a relational perspective, ${ }^{1}$ with parallels to process philosophy (Whitehead 1978), assemblage-network-theory (Latour 2007), and complex systems theory (Fischer and Riechers 2019). The common thread is that "relations between entities are more fundamental than the entities themselves" (Wildman 2006 in Walsh, Böhme, and Wamsler 2020, p. 3). This means that the primary objects of existence are continually unfolding processes and relations. No object can be understood outside its relation because the relation constitutes the object itself

\footnotetext{
${ }^{1}$ I use the word perspective when referring to ontology, epistemol-
} ogy and subsequent ethics and methodology to avoid complex jargon. 
(Barad 2007; West et al. 2020; Walsh, Böhme, and Wamsler 2020).

Bringing in transformation again begs the question of what the object of transformation is (Feola 2015). If relations exist prior to all other entities, then relations ought to be the object of transformation. It is essential to underline that relations are not framed in a dualistic sense as in between mindmatter or human-nature, but an ongoing entangled becoming of the world and its socio-ecological systems. This is best explained with Barad's term intra-action, suggesting an ongoing relation between entities (2007). This differs from interaction, which presumes the existence of separate entities (such as values) or things (such as coffee) that interact. Instead, entities such as values come to be in the moment of their intra-action and do not exist independently beforehand (Barad 2007; Walsh, Böhme, and Wamsler 2020). Similar to how relations exist prior to all else, intra-action refers to this process of relations that constitute the entity itself.

Building on this, meaning and matter are not static and separate elements, but an entangled, ongoing becoming, simultaneously productive of one another (Barad 2007). Values are thus not separate entities but come to be in the continual intra-action of the relations that configure the becoming of socio-ecological systems. This means that values are not only determined by the context within which they arise but also configure the unfolding materiality moment by moment. While the individual integrity of humans is respected, their being in this world is fundamentally understood as constituted by relations of all kinds (Walsh, Böhme, and Wamsler 2020, p. 7). Values as material-discursive practices differ from held values located within the mind, upholding the dichotomy between humans and nature, and from constructivist approaches by shifting the attention from structures to processes and relations. Such a relational perspective can, therefore, help explore and integrate "inner" and "outer" dimensions of sustainability, rather than studying values within these separate dimensions themselves (Ives, Freeth, and Fischer 2020).

How can such relational and processual notions of values be operationalized empirically? Empirical work focuses not on things or entities, but on experiences of practices and relations (Walsh, Böhme, and Wamsler 2020; Barad 2007). In this case, the ongoing relations between the soil, the sugar in the coffee cherries, people, and values enact the particular socio-ecological systems of coffee production in Burundi. Coffee production is a socio-ecological system with dynamic relations and entanglements of the world. However, as has been rightfully pointed out by West and colleagues (2020), despite adhering to a relational perspective where everything is connected in the ongoing becoming through intra-action, one has to start using words that separate entities from one another in writing. The challenge remains to say anything meaningful about such relations in isolation, without reproducing the binaries of human-nature (West et al. 2020). However, it is through the specific intra-actions that socioecological systems such as coffee production in Burundi are reconfigured. It is of interest to see how these specificities unfold by describing the intra-action of coffee production relations and the values that emerge through them (Barad 2007, p. 140).

\section{Setting and methods}

\section{Coffee production in Burundi}

Burundi is a small East African country that is also among the least developed globally (UNDP 2019). The vast majority of Burundians have spent the last five decades in severe multidimensional poverty with recurring ethnic-based violence (Uvin 2009; UNDP 2019). The recent political unrest with a failed coup d' état in 2015 underlines how intractable the cycle of conflict and violence in Burundi has become (Jobbins and Ahitungiye 2015; Vandeginste 2015). The political instability has led to "an institutionalized system of corruption, social exclusion, impunity, unpredictability, a total lack of accountability and clientelism" (Uvin 2009, pp. 109-110). Such tendencies are also seen in the coffee sector, which Burundi depends on for as much as 80 percent of their foreign exchange earnings (Lenaghan, Clay, and Kamwenubusa 2018).

Coffee production in Burundi has experienced a steady decline since 1990, with a subsequent decline in income for coffee farmers, despite its financial importance. The state is known for continuing unnecessary regulatory restrictions, resulting in severe management constraints for private actors (Lenaghan, Clay, and Kamwenubusa 2018). One regulation is that farmers are not allowed to process coffee. Only government- or privately-owned washing stations are granted permits to process and export coffee. Therefore, the "coffee producer" is a relationship between a coffee farmer and the specific washing station they choose to work with ${ }^{2}$ (Rosenberg 2017). The coffee producer entity, by definition being a relationship, makes it an interesting case study for exploring changes in a socio-ecological system in need of transformation from a relational perspective.

To summarize, Burundi has an ineffectively governed coffee sector, with declining production, few alternatives for export goods, and an institutionalized system of corruption. A recent report suggests that regulatory unpredictability and constraints retain state control of the increasingly unprofitable washing stations tied to the public sector (Lenaghan,

\footnotetext{
${ }^{2}$ In the rest of the paper, when I refer to a coffee producer, I refer to this relationship.
} 
Clay, and Kamwenubusa 2018). Due to the political and security instabilities discussed, doing business in Burundi remains costly and risky (Baghdadli, Harborne, and Rajadel 2008). There is therefore an agreement between government officials, Burundian coffee institutions, and private actors that Burundi's coffee sector will continue to decline and fail to "reverse course to profitable and sustainable sector in the long-term" (Lenaghan, Clay, and Kamwenubusa 2018, p. 12). In other words, the coffee-dependent country is in dire need of transformation toward sustainability. What are the current movements to make this happen, and what role do values play in this needed transformation toward sustainability?

The main approach to transform the Burundian coffee sector is to realize the possible quality and productivity potential in transitioning from cheap commodity coffee to higher valued specialty coffee (IMF 2012; WB 2016; Lenaghan, Clay, and Kamwenubusa 2018). By increasing productivity, quality, and coffee prices, 600,000 households that depend on coffee for their livelihoods could be lifted out of poverty. The World Bank and the International Monetary Fund have repeatedly focused on: (1) pressuring governance practices, (2) ecological requirements in terms of upgrading land-use practices, (3) technical processing requirements, and (4) monetary incentives for transforming Burundian coffee to quality coffee (IMF 2012; WB 2016; Lenaghan, Clay, and Kamwenubusa 2018). However, none of the reports (IMF 2012), grants (WB 2016) or policy recommendations (Lenaghan, Clay, and Kamwenubusa 2018) mention any aspect of the dynamic social-ecological systems as inherently relational, nor consider any social aspects of transformations toward sustainability.

\section{Study design}

This study pays specific attention to values to compensate for the void of relational aspects in current approaches to transform the Burundian coffee sector. Since the primary object of transformation from a relational perspective is relations, I explore how values in the coffee producer relation reconfigure the socio-ecological system of coffee production. This study investigates the relationship between farmers collaborating with the washing stations of one particular specialty coffee company. I chose to study this company due to its explicit goal to transform coffee farming in Burundi toward quality coffee by caring for both the coffee and the farmers that grow it (Gobo 2007). An entrepreneurial Christian couple moved to Burundi in 2013 and started the company due to the potential and need they noticed during a visit a few years earlier. It is therefore a relevant setting to explore the role of values in deliberate transformations toward sustainability within multifaceted challenges, such as working with small-scale farmers growing climate-sensitive coffee in depleted soil and multidimensional poverty and dealing with internationally volatile prices, a hostile business environment, political instability, poor infrastructure, and lack of essential goods (Baghdadli, Harborne, and Rajadel 2008). Due to this study's inductive nature, values emerged as a central part of the deliberate transformation process during data analysis.

The empirical evidence is based on participant observation and interviews carried out in Burundi during fieldwork between January and June 2017. I conducted 106 interviews with farmers, staff, and founders. They are in focus because they are the main stakeholders in this coffee producer relationship. I worked with a research assistant fluent in Kirundi and English since all farmers and some staff members spoke Kirundi. During the recorded interviews, the assistant could translate the responses with more time and attention. However, I did not record or take notes during field conversations according to recommended best practices for ethnographic fieldwork. An ongoing translation entailed a reduced translation quality that could not be verified later. Such translation issues were addressed to the degree possible by recommended strategies for ethnographic research (Emerson, Fretz, and Shaw 2011).

The approximately 55 Burundian small-scale coffee farmers in this study navigate war, disease, theft, poverty, climate change, and infertile soils. Coffee is their primary and often only cash crop. The annual payment for an average coffee farming family equates to about one dollar a month for a whole family, far below any poverty line. The 36 specialty coffee company staff included in this study serve in roles such as washing station managers, accountants, and agronomists. Most of them live in communities surrounding the company's washing stations, where they listen to farmers' concerns and assist farmers with coffee-related tasks during field visits. I have anonymized the informants and setting due to the political and security pressures discussed, which could put informants at grave risk.

The primary data source is field notes from participant observation while working as an intern for the company. I specifically chose ethnographic research, focusing on relational materialities suggested to suit materialist social inquiry (Fox and Alldred 2015). For instance, the materiality of coffee is not separable from any other related entity, such as the intra-action between soil, climate, farmers, country, and company, or the values within which the specific coffee production is configured (Barad 2007). Such an approach to relational materiality shifts the attention from studying what things are to what things do (Fox and Alldred 2015) and is therefore suited to examine the role of values as materialdiscursive practices rather than stable entities.

Being an intern for a coffee company came with positionality challenges, as expected, following the ethnographic participatory approach (Delamont 2007). While reflexivity 
can make us aware of the power-laden relations in the field, being aware does not make the power relations disappear (England 1994). Reflecting on the ethical dimensions of doing this work, I identified several potentially problematic aspects of my positionality, including the inability to obtain informed consent at all times and the friendships developed with informants. These issues were addressed through transparency and dialog to the extent possible yet highlight the inherently subjective and messy participatory research process.

\section{Results}

In the quest to understand the role of values in transformations toward sustainability, I present how values unfolded and were enacted. I have written this section in a personal tone, hoping to share the reality of coffee production in Burundi and to allow for a deeper appreciation for the emergence and importance of values in this context.

\section{Challenges}

I landed in Bujumbura, Burundi, on January 25th, 2017, eager to meet the people I was going to work with, get to know, and research. However, there were no people, cars, or messages waiting for me. Two company staff members arrived $30 \mathrm{~min}$ later, telling me in what felt like $100 \mathrm{~km}$ per hour English that they had just come from a meeting about a sudden change in law that was crippling the company. The government was banning collection points where farmers used to deliver their harvest of coffee close to home. Without such collection points, farmers are forced to carry backbreaking coffee bags directly to washing stations up to $25 \mathrm{~km}$ away. This walk was dangerous when slippery steep muddy paths stretched into hours of darkness. Soon, my days and months filled with nervous farmers telling me, "I am old, and I have a limp. It is tough for me to carry this far"; and the staff and founders grappling with how to compensate for the loss of collections points sourcing 40 percent of the company's coffee.

Uncertainty and unpredictability quickly became the constant rhythm of life. One law moved all USD business accounts to the national bank at an inflated exchange rate, and 33.7 percent of the company's capital dissipated overnight. Then extreme petrol shortages interfered with washing station operations that depended on $120 \mathrm{~L}$ of fuel daily for generators to process coffee. Cars lined up for days around petrol stations, only to get $10 \mathrm{~L}$ of fuel when they reached the pump. With no fuel, visiting farmers in far off hills, a vital part of this company's relational practice, was also at a standstill. Then there was the challenge of farming coffee in Burundi, a climate-sensitive crop in completely depleted soil and a changing climate. The Bourbon coffee trees grown in Burundi can yield five times more than the average Burundian coffee farmer producing a meager $800 \mathrm{gr}$ of coffee per tree. The fertilizer, which could only be ordered through the government and was paid for three months prior, did not arrive until the end of harvest, when it no longer could affect yield or quality. Even though it was only my second day, it was clear that it would require outstanding motivation to pull the coffee producers through these challenges, let alone to transform coffee production toward sustainability.

\section{Values unfolding}

Ethnography allowed me to discover what mattered to coffee producers and the manner in which the harvest of 2017 came to be. During the first few days, the founders kept asking staff members and me what the theme of this year should be. "What is important to us this year? How can we produce coffee in a way that we believe it ought to be?" On a long drive to one of the washing stations, we again discussed themes for the year. Once we arrived, a series of speeches were held, an essential practice in Burundi. The founder held a speech mentioning several of the company's values:

This company started with a vision to create an impact on one hill in Burundi. (...) It was not about making much money. We have a triple bottom line that is our vision and our foundation: 1) The first is the financial impact. Everyone needs to make a living; farmers, the team on the station, you, my family, US, and European coffee shops; that we can all make a living without taking advantage of anyone. 2) The second is social and environmental impact: that our neighboring farmers can send their children to school. That they can have better health, and that the environment becomes healthier. 3) The third is the kingdom's impact. It is the worldview following Jesus, which influences the decisions we make.

Then a staff member introduced himself with a speech starting with: "Thank you, God, thank you, team. You know me, I know you, and we know each other. Together!" The moment the staff member said "together," in synchronicity from different corners of the room, the founder, two staff members, and I turned to each other with eyes wide open and mouthed "together!" silently, nodded, and smiled. From that moment and onwards, I got to experience, observe, and partake in manifesting the value of "together" in practice. What is important here is that the togetherness value was formed due to a collective search for meaning and motivation. 


\section{Becoming with togetherness, care, dignity, and faith}

The next few months were spent preparing for the upcoming harvest by producing coffee legally and with care for coffee farmers. It was a challenge that seemed impossible at times in Burundi, where the expected norm was to break the law and cover it up with corruption. The company approached finding a solution to outlawed collection points by holding frequent dialog-based meetings. I spent most days in meetings and visiting farmers in their fields, where togetherness saturated plans, actions, and conversations. Farmers shared their frustration that this law was taking them back to slavery. Staff and junior agronomists approached farmers responding, "We understand your concerns, and that is why we are here, to think of solutions together." Farmers expressed how much they appreciated the contact the company kept with farmers. One farmer said, "The issue is that the other washing station does not treat us well. If they give this other washing station a collection point license, but not you, we see that something is not right!" Farmers were torn by refusing to deliver to washing stations closer to them but also being physically unable to deliver to this company's washing station on their own. Another farmer continued, "If we deliver to another washing station, they [government] will say, 'Now we got you!'. We demand that we stay together and that we work together. We see this law as acting as a game." Togetherness had clearly become a part of the coffee producer relationship.

Togetherness fits into a broader set of values observed, such as faith, care, and dignity. For instance, I observed the significance of faith in how farmers, staff, and founders spoke and acted. The importance of faith was evident by dedicating one of the company's bottom lines to Christian values. The farmers spent each Sunday in church and explained that "in everything we do, we put God first and thank him for everything". While the staff often started interactions with farmers with prayer, "as usual we'd like to start our meeting by praying, so I invite one of you to pray for us and for the activities that we want to start". Despite belonging to different denominations of Christianity, farmers, staff, and founders evidently valued faith by referring to the importance of God and practicing prayer in most interactions. Considerations about faith values being part of broader worldviews are discussed by other researchers (Christie, Gunton, and Hejnowicz 2019; Ives and Kidwell 2019), but have to be left aside here due to length constraints. However, it is significant to note how the value of faith became a central part of this coffee producer relationship and the way it became integral to coffee production.

Care was another pronounced value oriented toward the well-being of others, albeit in different ways. Farmers expressed care toward the family and their immediate community. One farmer was proud to share that "each day, these three women go to one of their lands to farm together. It is a great thing to see people help each other." Another farmer said, "It is important to me that my son is caring for his siblings." I observed that references to care were often linked to survival in a wider context. However, as crucial as coffee was for farmers' income, care was not observed to be expressed toward coffee among most farmers. There was therefore a difference in the way staff and founders extended care values compared to farmers. Staff and founders spoke of care and enacted care toward family, the broader community of coffee farmers, and the environment, including the intertwined relation between coffee, the rain forest, and soil.

Care values showed up frequently in the speeches and actions of the company. For example, the founders kept reminding the staff during meetings that "We serve the farmers. The farmers do not serve us". The founders referred consistently to farmers as their neighbors and/or friends, and the company as a coffee farming family, team, and community. The staff confirmed that "everyone is working. We are working as we were a family. Even the boss is not treating the laborers as simple people." Two staff members pointed out that their approach to others had changed toward dignity, equality, and respect due to the experience of working with people who acted out such values. However, I quickly realized that there was a subtle difference between claimed care values and enacted care values, and that it was imperative for the company to enact care in all domains of contact with the farmers.

\section{Transformational becoming}

It was the experience of enacted care values that proved to be transformational in fundamentally changing the relational aspects of coffee production. For instance, the company refused to celebrate before the farmers could do the same and postponed the Christmas party for the staff until farmers had been paid, an act communicating care and equality. The list of such seemingly minor actions was many, but among the ones most mentioned by farmers were the following: first, thanking farmers for making an effort to deliver to their washing station was employed as a routine practice among staff. Second, the company paid farmers in sealed envelopes. Each envelope had the farmer's name, hill, farmer card number, total harvest, and price written on it. Despite most farmers being illiterate, they explained that "envelopes are important in our culture because it is something official and shows respect." Farmers reported that they had not experienced coffee production as a practice of respect, dignity, and care before. Farmers expressed how being thanked each time at the washing station and paid in envelopes was meaningful in reshaping their own experience of self-worth and dignity, which is here considered as fundamentally changing relational aspects of coffee production. One farmer reported 
that: "The washing station is so far from our hill. There are stations closer, but going to yours has more advantages than others, and the [owners] are caring for farmers." Furthermore, farmers explained that reconfiguring what being a coffee farmer meant by experiencing coffee production with dignity and care motivated and incentivized them to take care of their coffee trees and improve their yield and quality, as called for in the transformation of the Burundian coffee sector.

The solution to the challenge of delivering coffee without collection points was formed collectively. Farmers and the company agreed to add a transport allowance to the price for each kilogram of coffee delivered, allowing farmers to pay for transport assistance or compensate for their added efforts. The season started, and the staff and founders wondered if farmers would come from as far as they said they would. Then an old farmer walked in from the most remote hill, with no coffee. He had heard a rumor that the founders were leaving and had come on behalf of many farmers wanting to double-check that their coffee would be accepted here. Farmers had organized themselves in groups and rented a bike for collective coffee transport. The old farmer told of an illegal roadblock checking that coffee cherries cannot pass the district border, despite the law allowing farmers to deliver to a washing station of their choosing. In response to this, the farmers planned to distract guards at the roadblock with a skit, allowing the coffee to pass unnoticed. They camouflaged the red coffee cherries with tomatoes on top, just in case. This farmer left again once he heard from staff that they support, encourage, and are grateful for farmers' efforts. The next day, the team nervously waited to see if farmers from this hill would make it safely. That they did. During the harvest season of 2017, the company produced 1093 tons of coffee, delivered by 4785 farmers. Nearly 2000 new farmers delivered coffee to the company's washing station in 2017, providing more than 17 per cent above project volume without collection points or petrol. Such results are analyzed as new outcomes, as called for by transformations toward sustainability.

\section{Expression of values}

References to the presented values were evident in the speeches, plans, and actions of the company. Explicit value expressions were so frequent that it was impossible to avoid relating to them. Below is a speech by the founder from when the company paid farmers a bonus in envelopes, with expressed values added in parentheses.

I want you to know that we are working together with you. (togetherness)
Last year the banks changed the rules.

[...]

But, we said we could do this because of two things.

Number one is we can trust in God, (faith)

Together we can trust in God. (togetherness, faith)

And the second thing; we have great coffee! So, we can push for a better price.

[...]

Together we make quality coffee. Together! (togetherness)

So, we took the coffee and the message, and we asked the people buying the coffee for more.

Not so we could eat.

But so together, we could share. (togetherness)

And so today, even though it is not a big premium, we have something to share. (well-being of others)

[...]

If we work together, we can overcome any challenge. (togetherness)

Because together we have overcome the changes in the rules, (togetherness)

And we can share the reward together. (togetherness)

[...]

But we can only do this together. (togetherness)

And we can only do this with God. (faith)

So, I want to thank you for being together. (dignity and togetherness)

Looking at the crowd during this speech, I noticed that farmers and staff nodded, sighed, and placed their hands on their heart, indicating a sense of accord when the founder referred to values. In summary, despite limited fuel, finances, and no collection points, 2000 new farmers chose to walk long distances to deliver to this particular company, resulting in an unexpected increase in coffee volume produced. The values of togetherness, dignity, care, and faith were an entangled part of the coffee producer relations, enacting outcomes indicated by the increased number of farmers and coffee volume. And again, if relations are the primary objects of transformation that reconfigure socio-ecological systems of coffee production, then values clearly play a role in how these relations unfold. Furthermore, this study shows that values can be formed and chosen deliberately by the intentional search for the togetherness value, which was formed and enacted during the coffee season of 2017. The next section discusses the repercussions of these findings for the role of values in transformations toward sustainability. 


\section{Discussion: do values matter for transformations?}

\section{How material-discursive practices are transformative}

This paper explores the role of values in transformations toward sustainability. The point of departure being the relational perspective of new-materialism (Barad 2007; Walsh, Böhme, and Wamsler 2020), entails adjusting the definition of sustainability to transformations as fundamental changes of relational aspects of socio-ecological systems that lead to new outcomes (drawn on Patterson et al. 2017, p 2). Here, the objects of transformation are considered the relations that exist prior to all else (Feola 2015; West et al. 2020; Barad 2007). To operationalize it empirically, these relations are limited to the socio-ecological system of coffee production in one specialty coffee company in Burundi. I find that values are part of the moment-by-moment relations that make this world. Values that are manifested through these relations define the patterns of intra-action and therefore the unfolding outcomes.

This paper suggests approaching values as materialdiscursive practices (Barad 2007). This means that values are part of configuring the relations that produce coffee and the world in specific ways (Barad 2007). For instance, farmers set out on slippery, muddy paths at night and found creative ways to transport up to $500 \mathrm{~kg}$ coffee bags as far as $25 \mathrm{~km}$, bypassing other washing stations. The fact that nearly 2000 new farmers delivered coffee to the company's washing station in 2017 and produced 17 per cent above projected volume without collection points or petrol is considered a new outcome of the intra-active socio-ecological coffee production system, as called for by transformations toward sustainability (Patterson et al. 2017; Walsh, Böhme, and Wamsler 2020). These findings align with Barad's claim that "different material-discursive practices produce different material configurings of the world" (2007, p 184).

However, to qualify as transformations toward sustainability, they need to be achieved by fundamental change in the relational aspects of socio-ecological systems (Patterson et al. 2017; Barad 2007). I argue that values play the role of configuring the relations that make this world moment by moment, and in such, provide details of the relational aspects of transformations. People in this study continuously voiced values in conversations, speeches, and actions. By making them so explicit, they introduced and reproduced ideas about what mattered to people in this specific coffee producer relationship. The expressions of gratitude at the washing station and the payment in envelopes can be considered as the material-discursive practices of dignity and care. These lived experiences of being treated respectfully were part of reconfiguring farmers' reported sense of self-worth and dignity. Such simple acts of gratitude and respect can seem mundane yet were transformative for farmers who spoke of coffee farming feeling like slavery where they were treated more like animals than humans. The point is that the lived experience of producing coffee with the values of dignity was a different pattern of being from producing coffee without dignity. Being treated with care and dignity as humans changed the very experience of being a coffee farmer and is therefore considered a transformative becoming. The practices of togetherness, care, dignity, and faith shaped the unfolding relations by how the staff and founders ran the company, met with people, communicated, and practiced coffee production. It was a relational way of being, thinking, and acting (Walsh, Böhme, and Wamsler 2020). I find that the enactments of these values fundamentally changed the relational aspects of coffee production, as called for in transformations toward sustainability (Patterson et al. 2017).

How are values central to achieving desired sustainability outcomes, such as ensuring the quality of Burundian coffee (Lenaghan, Clay, and Kamwenubusa 2018)? For instance, whether farmers transported coffee via a road, or a path proved to be defining for the outcome of coffee production in several ways. Due to the unfolding dynamic between banned collection points, poverty, and the petrol shortage, the majority of coffee farmers harvested coffee during the day and carried their harvest on foot at night. The steep muddy paths were taken to produce coffee at a washing station entangled with values of togetherness, care, dignity, and faith. This long journey meant that coffee cherries got processed later, and time became an entangled part of the unfolding coffee production. The sugar in the coffee cherries started fermenting and the coffee's clean quality desired in the specialty coffee market started to fade, a challenge when the aim was to transform the Burundian coffee sector from commodity to specialty coffee (Lenaghan, Clay, and Kamwenubusa 2018; WB 2016).

Such processes of coffee production cannot be detached from values formed and manifested through the coffee producer relationship. Farmers walked and carried their coffee for a slightly better coffee price, but also to be treated with care, to be part of the collective becoming in a certain way. To experience becoming together, with dignity. This illustrates how the quality of the coffee is a manifestation of the dynamic relation between values, time, muddy paths, and sugar molecules. This shows how the relational aspects of values are central to the process of a coffee farmer carrying a bag of coffee to a washing station far away from their farm in Burundi in 2017. They were in the process of making 
the world. As material-discursive practices, values play an active role in coffee production, both in the lived experience of coffee producers and in the material quality that coffee drinkers experience. Values are found to be both ideas of what people collectively deemed to matter and manifestations of the very same ideas in unfolding material articulations (Kenter et al. 2019; Barad 2007). Neglecting the role of values in sustainability-oriented practices would ignore the vital part of values in the relation that configures the socioecological systems meant to be transformed.

Values clearly play a crucial role in the transformation of the relations that intra-act and result in the socio-ecological system of coffee production in Burundi. Focusing on the technical and ecological aspects of transforming the Burundian coffee sector toward sustainability has resulted in coffee farmers without incentives to increase the productivity or quality of their coffee (Lenaghan, Clay, and Kamwenubusa 2018). Based on this study, I suggest that neglecting the dynamic socio-ecological aspects means neglecting the relationality of how the world unfolds (Shrivastava et al. 2020; West et al. 2020). This study has shown that values can reconfigure coffee production to result in increased collaboration, coffee volume, and retained quality despite grave material and managerial challenges. By paying attention to the role of values, we see how central values are to the relational aspects of coffee production, because coffee production is a relational process after all, like any socioecological system (West et al. 2020; Walsh, Böhme, and Wamsler 2020).

\section{Value change}

The argument so far is that values are central to the transformation of relations configuring the socio-ecological coffee production systems and their outcomes. However, I also find that values can and do change. The assertion that values can change requires revisiting the dominant value perspectives. The majority of values literature considers values as inherently separate from the material world by assuming that individuals hold values as entities in the mind (Rokeach 1973; Schwartz 1994). Held values are seen as barriers to sustainability transformations because they change slowly. Furthermore, held values can be identified and felt, but not necessarily acted upon it. They are then neither part of unfolding relations, material outcomes, nor transformational change (Everard, Reed, and Kenter 2016; Nielsen and Reenberg 2010). Dominant constructivist approaches, on the other hand, consider values as continually forming outside the mind in systemic structures (Kenter et al. 2019). However, both perspectives uphold the binary between the social and ecological by concentrating on entities rather than inherently dynamic unfolding relations of socio-ecological systems (West et al. 2020; Walsh, Böhme, and Wamsler 2020; Shrivastava et al. 2020).

Recent studies suggest that values can form over time during the socialization processes that allow people to interact and reflect on what matters to them (Everard, Reed, and Kenter 2016). This study has provided many examples of such socialization processes, but theoretically considers these as intra-actions rather than interactions. This difference requires nuancing the idea of forming values as separate entities, which does not align with the relational perspective of new materialism. If we approach the socialization process as a relational becoming where values are materialdiscursive practices, expressed, re-forming, and intra-acting within the unfolding material articulations, then values are part of the active articulation of the world in which we have our being. Values are of this world, rather than fixed entities in the mind, or fluid entities outside the mind upholding social structures.

This study has shown that the value of togetherness was deliberately searched for, formed collectively, and manifested in unfolding coffee production relations. This was initiated by the founders, but the search for meaning was a collective and intra-active process that included not only the perspectives from various people, but also the material constraints of the system. Togetherness was manifested as a material-discursive practice during a challenging coffee harvest spanning over six months, not during a generation. What is noteworthy in this study is also the manner in which values were formed and unfolded. The process was tolerant and inclusive by forming and manifesting shared values, rather than aiming to change values in specific ways. Tolerant and inclusive change processes are in line with how sustainability transformations ought to come about ("The 2030 Agenda" 2015; Ravenscroft 2019). The point here is that values can and do change as part of the ongoing relations configuring the world.

At the same time, it is worth mentioning that faith values had been central to most of the informants throughout life. Considering such constant faith values as material-discursive practices entails that these values are continuously chosen and maintained by individuals as they experience and enact their lives in ongoing socio-ecological systems. Yet, as material-discursive practices, there is no expectation that faith values will persist, but that they were observed as part of the way this coffee production unfolded. It is an openended approach to values that acknowledges the histories of becoming, without defining the future trajectories based on what came before the specific relational intra-actions.

The previous section asserts that the role of values is to transform relations, because everything that arises from these relations is transformed, being coffee or cognitive aspects of being human of this world. Building on this, I 
further argue that the role of values is to transform the way in which these relations unfold by choosing what values to enact and prioritize. The intentional agent is purposefully undefined because it is inherently relational. It can be an individual, community, company, coffee producer relationship, government ministry, or a scientific advisory board. The relations constituting the agent can choose what values to manifest. Enacting values by voicing them and manifesting them in policies and actions can transform relations we have to each other, our co-workers, friends, enemies, strangers, nature, and the climate. It sounds easy, and yet it is not. It is a constant fight to choose equality, dignity, respect, and care, amid competition, authority, and power.

\section{Conclusion: values matter for sustainability transformations}

The central thesis of this paper is that what people care about matters in a material and spiritual sense. I argue that values are the differences that matter based on two main findings. First, values are material-discursive practices, meaning that they play the role of configuring the unfolding materiality, such as sustainability outcomes. Second, values can and do change, meaning that which values to intentionally manifest is a choice to a higher degree than previously thought. The repercussion of this combination is that we can and need to choose values such as dignity, equality, safety, and harmony for people and nature in our relations to one another and the world (Agenda 2030). Paying more attention to which values we prioritize can make sure that we deliberately choose and manifest values that are to a higher degree consistent with an equitable and sustainable world.

\begin{abstract}
Acknowledgements This work would not have been possible without the coffee company and the coffee farmers letting me partake in producing coffee (and the world) together. I am also grateful for the invaluable support and feedback from Karen O'Brien, Morgan Scoville-Simonds, and Irmelin Gram-Hanssen. Thank you to the Research Council of Norway for funding The Role of Global Value Chains in Transitions to Sustainability project (255664).
\end{abstract}

Funding Open access funding provided by University of Oslo (incl Oslo University Hospital).

Open Access This article is licensed under a Creative Commons Attribution 4.0 International License, which permits use, sharing, adaptation, distribution and reproduction in any medium or format, as long as you give appropriate credit to the original author(s) and the source, provide a link to the Creative Commons licence, and indicate if changes were made. The images or other third party material in this article are included in the article's Creative Commons licence, unless indicated otherwise in a credit line to the material. If material is not included in the article's Creative Commons licence and your intended use is not permitted by statutory regulation or exceeds the permitted use, you will need to obtain permission directly from the copyright holder. To view a copy of this licence, visit http://creativecommons.org/licenses/by/4.0/.

\section{References}

Baghdadli I, Richard H, Tania M (2008) Breaking the cycle: a strategy for conflict-sensitive rural growth in Burundi." World Bank Working Paper NO. 147. The World Bank. https://doi.org/10. 1596/978-0-8213-7561-7

Barad K (2007) Meeting the Universe Halfway: quantum physics and the entanglement of matter and meaning. Duke University Press, Durham

Bardi A, Schwartz S (2003) Values and behavior: strength and structure of relations. Pers Soc Psychol Bull 29(10):1207-1220. https://doi. org/10.1177/0146167203254602

Blackburn S (2018) What does transformation look like? Post-disaster politics and the case for progressive rehabilitation. Sustainability 10(7):2317. https://doi.org/10.3390/su10072317

Christie I, Gunton R, Hejnowicz A (2019) Sustainability and the common good: catholic social teaching and 'integral ecology' as contributions to a framework of social values for sustainability transitions. Sustain Sci 14(5):1343-1354. https://doi.org/10.1007/ s11625-019-00691-y

Curry GN, Koczberski G, Lummani J, Nailina R, Peter E, McNally G, Kuaimba O (2015) A bridge too far? The influence of socio-cultural values on the adaptation responses of smallholders to a devastating pest outbreak in cocoa. Glob Environ Chang 35(November):1-11. https://doi.org/10.1016/j.gloenvcha.2015.07.012

Delamont S (2007) Ethnography and participant observation. Qualitative reserach practice. Sage Publications, London, pp 205-217

Emerson RM, Fretz RI, Shaw LL (2011) Writing ethnographic fieldnotes. The University of Chicago Press, London

England KV (1994) Getting personal, reflexivity, positionality, and feminist research. Prof Geogr 46(1):80-89

England J (2004) Disciplining subjectivity and space: representation, film and its material effects. Antipode 36(2):295-321. https://doi. org/10.1111/j.1467-8330.2004.00407.x

Everard M, Reed MS, Kenter JO (2016) The ripple effect: institutionalising pro-environmental values to shift societal norms and behaviours. Ecosyst Serv 21(October):230-240. https://doi.org/ 10.1016/j.ecoser.2016.08.001

Fazey I, Moug P, Allen S, Beckmann K, Blackwood D, Bonaventura M, Burnett $\mathrm{K}$ et al (2018) Transformation in a changing climate: a research agenda. Climate Dev 10(3):197-217. https://doi.org/ 10.1080/17565529.2017.1301864

Feola G (2015) Societal transformation in response to global environmental change: a review of emerging concepts. Ambio 44(5):376390. https://doi.org/10.1007/s13280-014-0582-z

Few R, Morchain D, Spear D, Mensah A, Bendapudi R (2017) Transformation, adaptation and development: relating concepts to practice. Palgrave Commun 3(1):1-9. https://doi.org/10.1057/ palcomms.2017.92

Fischer J, Riechers M (2019) A leverage points perspective on sustainability. People Nat 1(1):115-120. https://doi.org/10.1002/pan3.13

Ford RM, Williams KJH, Bishop ID, Webb T (2009) A value basis for the social acceptability of clearfelling in Tasmania, Australia. Landsc Urban Plan 90(3):196-206. https://doi.org/10.1016/j.landu rbplan.2008.11.006

Fox NJ, Alldred P (2015) New materialist social inquiry: designs, methods and the research-assemblage. Int J Soc Res Methodol 18(4):399-414. https://doi.org/10.1080/13645579.2014.921458

Gobo G (2007) Sampling, representativeness and generalizability. Qualitative reserach practice. Sage Publications, London, pp 405-427

Haraway DJ (1991) Simians, cyborgs, and women: the reinvention of nature. Routledge, New York

Harvey D (1996) Justice, nature, and the geography of difference. Blackwell Publishers, Cambridge, Mass 
Hicks CC, Cinner JE, Stoeckl N, McClanahan TR (2015) Linking ecosystem services and human-values theory. Conserv Biol 29(5):1471-1480. https://doi.org/10.1111/cobi.12550

Hochachka G (2020) Unearthing insights for climate change response in the midst of the COVID-19 pandemic. Global Sustain. https:// doi.org/10.1017/sus.2020.27

Hyams M (2003) Adolescent latina bodyspaces: making homegirls, homebodies and homeplaces. Antipode 35(3):536-558. https:// doi.org/10.1111/1467-8330.00338

International Monetary Fund (2012) Burundi: Poverty Reduction Strategy Paper. IMF Country Report. 12/224. Washington DC: IMF

Ingold T (2004) Beyond biology and culture: the meaning of evolution in a relational world. Soc Anthropol 12(2):209-221. https://doi. org/10.1111/j.1469-8676.2004.tb00102.x

Irvine KN, O'Brien L, Ravenscroft N, Cooper N, Everard M, Fazey I, Reed MS, Kenter JO (2016) Ecosystem services and the idea of shared values. Ecosyst Serv 21(October):184-193. https://doi.org/ 10.1016/j.ecoser.2016.07.001

Ives CD, Kendal D (2014) The role of social values in the management of ecological systems. J Environ Manage 144(November):67-72. https://doi.org/10.1016/j.jenvman.2014.05.013

Ives CD, Kidwell J (2019) Religion and social values for sustainability. Sustain Sci 14(5):1355-1362. https://doi.org/10.1007/ s11625-019-00657-0

Ives CD, Freeth R, Fischer J (2020) Inside-out sustainability: the neglect of inner worlds. Ambio 49(1):208-217. https://doi.org/ 10.1007/s13280-019-01187-w

Jobbins M, Ahitungiye F (2015) Peacebuilding and conflict prevention in Burundi's 2015 election crisis. Global Summitry 1(2):205-218. https://doi.org/10.1093/global/guw003

Kenter JO, Raymond CM, van Riper CJ, Azzopardi E, Brear MR, Calcagni F, Christie I et al (2019) Loving the mess: navigating diversity and conflict in social values for sustainability. Sustain Sci 14(5):1439-1461. https://doi.org/10.1007/s11625-019-00726-4

Kuruppu N (2009) Adapting water resources to climate change in Kiribati: the importance of cultural values and meanings. Environ Sci Policy 12(7):799-809. https://doi.org/10.1016/j.envsci.2009.07.005

Latour B (2007) Reassembling the social: an introduction to actor-network-theory. Clarendon Lectures in Management Studies. Oxford Univ. Press, Oxford

Lenaghan T, Clay D, Kamwenubusa E (2018) Burundi Coffee Sector: Strategic Policy Analysis. Technical Report, Africa Great Lakes Region Coffee Support Program (AGLC)

Lovejoy AO (1950) Terminal and adjectival values. J Philos 47(21):593-608. https://doi.org/10.2307/2021804

Mansfield N (2000) Subjectivity: theories of the self from Freud to Haraway. New York University Press, New York

Massey D (1994) Space, place and gender. Polity Press, Cambridge

Meadows Donella H (1999) Leverage Points. Places to Intervene in a System. The Sustainability Institute, Hartland

Nielsen JØ, Reenberg A (2010) Cultural barriers to climate change adaptation: a case study from Northern Burkina Faso. Global Environ Change 20(1):142-152. https://doi.org/10.1016/j.gloen vcha.2009.10.002

Parker B (2016) feminist forays in the city: imbalance and intervention in urban research methods. Antipode 48(5):1337-1358. https:// doi.org/10.1111/anti.12241

Patterson J, Schulz K, Vervoort J, van der Hel S, Widerberg O, Adler C, Hurlbert M, Anderton K, Sethi M, Barau A (2017) Exploring the governance and politics of transformations towards sustainability. Environ Innov Soc Trans 24(September):1-16. https://doi.org/10. 1016/j.eist.2016.09.001

Poortinga W, Whitmarsh L, Steg L, Böhm G, Fisher S (2019) Climate change perceptions and their individual-level determinants: a cross-European analysis. Glob Environ Chang 55:25-35. https:// doi.org/10.1016/j.gloenvcha.2019.01.007
Pulido L (2000) Rethinking environmental racism: white privilege and urban development in Southern California. Ann Assoc Am Geogr 90(1):12-40. https://doi.org/10.1111/0004-5608.00182

Ravenscroft N (2019) A new normative economics for the formation of shared social values. Sustain Sci 14(5):1297-1307. https://doi. org/10.1007/s11625-018-0652-4

Rawluk A, Ford R, Anderson N, Williams K (2019) Exploring multiple dimensions of values and valuing: a conceptual framework for mapping and translating values for social-ecological research and practice. Sustain Sci 14(5):1187-1200. https://doi.org/10.1007/ s11625-018-0639-1

Rohan M (2000) A rose by any name? The values construct. Pers Soc Psychol Rev 4(3):255-277

Rokeach M (1973) The nature of human values. The Free Press, New York

Rosenberg L (2017) Turi Kumwe (We Are Together): A Transdisciplinary Exploration of the Burundian Specialty Coffee Sector and Its Sustainability Challenges. Stellenbosch University $\mathrm{PhD}$ Thesis

Salomaa A, Juhola S (2020) How to assess sustainability transformations: a review. Global Sustain. https://doi.org/10.1017/sus.2020.17

Schulz C, Martin-Ortega J, Glenk K (2018) Value landscapes and their impact on public water policy preferences. Glob Environ Chang 53(November):209-224. https://doi.org/10.1016/j.gloenvcha. 2018.09.015

Schwartz SH (1994) Are there universal aspects in the content of human values? J Soc Issues 50(4):19-45

Schwartz SH, Bilsky W (1990) Toward a theory of the universal content and structure of values: extensions and cross-cultural replications. J Pers Soc Psychol 58(5):878. https://doi.org/10.1037/ 0022-3514.58.5.878

Schwartz SH, Sagie G (2000) Value consensus and importance: a crossnational study. J Cross Cult Psychol 31(4):465-497. https://doi. org/10.1177/0022022100031004003

Shrivastava P, Smith MS, O’Brien K, Zsolnai L (2020) Transforming sustainability science to generate positive social and environmental change globally. One Earth 2(4):329-340. https://doi.org/10. 1016/j.oneear.2020.04.010

The 2030 Agenda (2015) A/RES/20/1. Springer Publishing Company, New York, NY. https://doi.org/10.1891/9780826190123.ap02

UNDP (2019) Human development report. Bernan press

Uvin P (2009) Life after violence: a people's story of Burundi. African Arguments. Zed, London; New York

Vandeginste S (2015) Burundi's electoral crisis-back to power-sharing politics as usual? Afr Aff 114(457):624-636. https://doi.org/ 10.1093/afraf/adv045

Walsh Z, Böhme J, Wamsler C (2020) Towards a relational paradigm in sustainability research, practice, and education. Ambio Febr. https://doi.org/10.1007/s13280-020-01322-y

World Bank (2016) International Development Association Project Appraisal Document on a Proposed Grant to the Republic of Burundi for a Coffee Sector Competitiveness Project. Agricultural Global Practice, Africa Region

West S, Jamila Haider L, Stålhammar S, Woroniecki S (2020) A relational turn for sustainability science? Relational thinking, leverage points and transformations. Ecosyst People 16(1):304-325. https://doi.org/10.1080/26395916.2020.1814417

Whitehead AN (1978) "Process and reality". Free Press, New York

Wolf J, Allice I, Bell T (2013) Values, climate change, and implications for adaptation: evidence from two communities in Labrador, Canada. Glob Environ Chang 23(2):548-562. https://doi.org/10. 1016/j.gloenvcha.2012.11.007

Publisher's Note Springer Nature remains neutral with regard to jurisdictional claims in published maps and institutional affiliations. 